КРАВЧЕНКО

Оксана Михайлівна o.m.kravchenko@opu.ua
УДК 339.94:330.34:004

ТРЕНД АНАЛІЗ ЧУТЛИВОСТІ МІЖНАРОДНОГО БІЗНЕСУ СФЕРИ ІНФОРМАЦІЙНИХ ТЕХНОЛОГІЙ ДО ГЛОБАЛЬНИХ ОБМЕЖЕНЬ
САПОЖНІКОВА

Слизавета Василівна yelyzaveta.sapozhnikova@mzeid.in

\section{TREND ANALYSIS OF THE SENSITIVITY OF INTERNATIONAL BUSINESS IN THE FIELD OF INFORMATION TECHNOLOGIES TO GLOBAL LIMITATIONS}

к.е.н., доцент, Одеський начіональний політехнічний університет
DOI: https://doi.org/10.37634/efp.2020.12(4).3 студентка, Одеський національний політехнічний університет

KRAVCHENKO Oksana Mykhailivna - PhD in Economics, Associate Professor, Odesa National Polytechnic University

SAPOZHNIKOVA Yelyzaveta Vasylivna - student, Odesa National Polytechnic University

У статті розглянуто тенденції міжнародного бізнесу сфери інформаційних технологій в умовах глобальних обмежень, пов'язаних із пандемією Covid-19. Надано аналітичні прогнози розвитку сфери інформаційних технологій. Виявлено, щзо, попри видимість зростання сфери інформачійних технологій, у зв'язку з пандемією та переходом великої кількості операчій в онлайн, загалом спостерігається ії скорочення. Проте більш детальний аналіз показує неоднорідність иьього процесу, ияо характеризується зростанням попиту на окремі послуги сфери інформаційних технологій, та наявність відкладеного попиту у сферах, щңо зазнали спаду. Це дає змогу стверджувати, щэо в перспективі можна очікувати відновлення стрімкого зростання попиту на більшість послуг інформаційних технологій.

В статье рассмотрены тенденции международного бизнеса сферы информационных технологий в условиях глобальных ограничений, связанных с пандемией Covid-19. Предоставлены аналитические прогнозы развития сферы информационных технологий. Обнаружено, что несмотря на видимость роста сферы информачионных технологий, в связи с пандемией, и переходом большого количества операщий в онлайн, в целом наблюдается ее сокращение. Однако, более детальный анализ показывает неоднородность этого процесса, что характеризуется ростом спроса на отдельные услуги сферы информационных технологий, и наличие отложенного спроса в сферах, подвергшихся спада. Это позволяет утверждать, что в перспективе можно ожидать восстановления стремительного роста спроса на большинство услуг информационных технологий.

$$
* * *
$$

The paper examines the trends of international business in the field of information technology in the context of global constraints associated with the Covid-19 pandemic. In terms of global restrictions, the role of information technology development in the resilience of companies to changes in the external environment and ensuring the possibility of business survival is particularly acute. Analytical IT forecasts need to be considered to be ready for change. It was found that despite the appearance of growth in the field of information technology, due to the pandemic, and the transition of a many number of operations online, in general, there is a reduction. These trends are due to the fact that in the crisis caused by the Covid-19 pandemic, most companies and individuals will delay the modernization of hardware and software, trying to use what already exists. However, a more detailed analysis shows the heterogeneity in the change in demand for certain types of information technology services. Thus, there is an increase in such information technology services as public cloud services and video conferencing, and the presence of deferred demand in declining areas. At the same time, it can be argued that in the long run we can expect a resumption of rapid growth in demand for most information technology services, the consumption of which has been postponed. Today, software vendors help companies of all sizes and industries survive, grow and grow. We looked at the ten most profitable IT companies in the world in 2020. All of them have the highest revenue as of November 18, 2020. The ranking includes mainly US companies, countries with developed post-industrial economies. Almost $80 \%$ of US GDP is accounted for by services, which has made them a world leader in this segment. Material production accounts for only $20 \%$ of GDP, including all industries, agriculture and forestry, construction. Focus on scientific and technological progress is one of the hallmarks of an effective economic system. Given the current trends in the development of IT technologies, we can say that they are the driving force of global transformation and economic growth of the world, as well as increase the competitive advantage of any economic entity.

Ключові слова: інформаційні технології, міжнародний бізнес, чутливість до обмежень, тренд аналіз

Ключевые слова: информационные технологии, международный бизнес, чувствительность к ограничениям, тренд анализ

Keywords: information technology, international business, sensitivity to constraints, trend analysis

\section{ВСТУП}

Сучасні світові тенденції характеризуються прагненням до постійного розвитку та вдосконалення продукції, що виробляється, способів представлення та реалізації продукції споживачам, оптимізації логіс- тичних процесів. За останнє десятиліття кількість процесів, що проходять без використання інформаційних технологій постійно скорчується, що стосується і сфери виробництва, і сфери послуг. В умовах глобальних обмежень, з якими стикнувся світ у 2020 р., 
це відчувається особливо гостро. Роль розвитку сфери інформаційних технологій у стійкості до змін у зовнішньому середовищі та забезпеченні можливості виживання бізнесу значно зросла.

МЕТА роботи - визначення основних трендів розвитку інформаційних технологій у сучасному світі та проведення аналізу чутливості міжнародного бізнесу сфери інформаційних технологій до глобальних обмежень.

\section{МЕТОДИ ДОСЛІДЖЕННЯ}

У статті використовувалися такі методи дослідження, як: метод наукової абстракції, статистичних спостережень, аналіз та синтез, методи індукції та дедукції.

\section{РЕЗУЛЬТАТИ}

Використання інформаційних технологій (IT) підприємствами різних сфер господарювання набуває все більше значимості у забезпеченні конкурентоспроможності, управлінні компанією, а також стає невід'ємною складовою ведення бізнесу на міжнародному рівні.

Питанню дослідження трендів ринку інформаційних технологій була приділена значна увага у численних роботах вітчизняних та зарубіжних науковців, зокрема I.І. Ковальчук, Л.Г. Саркісян, Л.С. Довгань, А.В. Козинець та ін.

Розвиток IT надає великі можливості для підприємств: скорочення часу на створення нових продуктів із використанням інструментів автоматизованого проєктування; оптимізація процесу за допомогою комп’ютерних систем управління, які вводять правила прийняття експертних рішень; за допомогою системи планування, яка об'єднує дослідження і виробництво, водночас виробничу лінію можна швидко змінити. Правильне впровадження й використання IT дозволяє компаніям йти в ногу з часом, відповідати сучасним тенденціям розвитку бізнесу та зробити їх конкурентоспроможними на міжнародному ринку.

Щоб бути готовими до змін потрібно враховувати аналітичні IT-прогнози [1]. Основні 3 них:

1) до 2022 р. понад $60 \%$ глобального ВВП буде надходити від цифрових технологій та рішень. Ті виробники, які не зможуть відцифрувати свої операції і пропозиції, програють конкурентам, оскільки традиційний ринок незабаром відійде в минуле;

2) до 2023 р. $75 \%$ всіх витрат на ІТ будуть пов'язані 3 розробленням платформ для просування продукції. Понад $90 \%$ всіх підприємств створять власні цифрові IT-середовища для подальшого розвитку в умовах цифрової економіки;

3) до 2022 р. понад 40 \% хмарних організацій будуть використовувати периферійні обчислення (edge computing), a 25 \% кінцевих пристроїв і систем будуть виконувати їх за допомогою алгоритмів штучного інтелекту. Периферійні обчислення - це метод оптимізації хмарних обчислювальних систем шляхом виконання обробки даних на периферії мережі, недалеко від джерела. Він не тільки підвищує ефективність використання додатків для обчислень і роботи 3 да- ними, а й сприяє більш активному впровадженню новітніх технологій, таких як штучний інтелект і 5G-комунікації;

4) за період 2018-2023 pp. буде створено більше додатків, ніж за останні 40 років. Завдяки новим інструментам та платформам, великій кількості розробників, гнучким методам і можливості повторного використання коду за 2018-2023 рр. буде створено 500 млн нових додатків, що перевершує кількість програм, створених за попередні 40 років;

5) до 2024 р. 90 \% організацій будуть використовувати гібридні хмарні технології й інструменти.

Наведені тенденції ілюструють великий потенціал розвитку IT-сектору в усьому світі. Водночас з огляду на мінімальні обсяги інвестицій, що необхідні для розвитку IT-сфери, порівнюючи з виробничою, та наявність достатньо великої кількості людських ресурсів - потенційних кваліфікованих кадрів, можна сказати, що за умов державного сприяння, IT сфера може стати однією з лідируючих в економіці України.

У січні 2020 р. дослідницький центр Gartner (США) спрогнозував зростання ринку IT-послуг у 2020 р. на 3,4 \%, відносно 2019 р. [2]. Не зважаючи на наведені вище тенденції, що характеризуються тотальним зростом попиту на послуги IT, пов'язаним із пандемією, та переходом більшості робіт в онлайн, у травні 2020 p. Gartner переглянув попередній прогноз, складений у січні, та склав новий, що свідчить про просідання ринку IT послуг у 2020 р. на 8 \% [3]. Найбільшний спад очікується на ринку електронних пристроїв, зокрема комп'ютерів і смартфонів. Тут продажі у 2020 р. знизяться на 15,5\%. Аналітики Gartner прогнозують зменшення на 9,7\% світових витрат на системи для дата-центрів, спад на 7,7\% і 6,9\% у сегментах ІТ-послуг і корпоративного ПО відповідно. Ми погоджуємось із дослідниками Gartner, які вважають, що такі тенденції пов'язані з тим, що в кризових умовах, які склались внаслідок пандемії Covid-19, більшість компаній будуть відкладати модернізацію техніки та програмного забезпечення, намагаючись використовувати те, що вже $\epsilon$. На нашу думку, торкнеться це і фізичних осіб, які через скорочення, або втрату джерел доходів, намагатимуться максимально скоротити витрати, надаючи перевагу безоплатним сервісам та програмному забезпеченню.

Водночас аналітики Gartner кажуть про те, що на $19 \%$ мають зрости витрати на публічні хмарні сервіси, на 8,8 \% - на хмарну телефонію й месенджери, на 24,3\% - на відеоконференц зв'язок, чому сприяє масовий перехід компаній на віддалену роботу [3]. Насправді зростання попиту на хмарні сервіси було прогнозовано ще у 2019 р. (табл. 1) [4].

Ми бачимо, що за чотири роки очікується зростання доходу від публічних хмарних сервісів у 1,82 рази, або на $82 \%$, тобто майже вдвічі. Також ми бачимо, що згідно з табл. 1, зростання доходу від хмарних сервісів у 2020 р., відносно 2019 р., було прогнозовано на рівні $17 \%$, сьогодні ж експерти кажуть про те, що за підсумками 2020 р, цей показник складе $19 \%$, тобто на 2 \% більше, ніж було прогнозовано. 
Світовий прогноз доходу від публічних хмарних сервісів (млрд дол. США) [4]

\begin{tabular}{|l|c|c|c|c|c|}
\hline Показник & 2018 & 2019 & 2020 & 2021 & 2022 \\
\hline $\begin{array}{l}\text { Світовий обсяг доходу від публічних хмарних сервісів, } \\
\text { млрд дол. США }\end{array}$ & 182.4 & 214.3 & 249.8 & 289.1 & 331.2 \\
\hline Темпи приросту & - & 1,18 & 1,17 & 1,16 & 1,15 \\
\hline Темпи росту & - & 1,18 & 1,37 & 1,59 & 1,82 \\
\hline
\end{tabular}

Ринок хмарних сервісів України не тільки наслідує міжнародні тенденції, але й випереджає. Так, у 2014 р. ринок хмарних сервісів України становив трохи більш ніж 5 млн дол. США, тоді як станом на 2020 р. обсяг ринку хмарних сервісів України перевищив 23 млн дол. США [5]. Тобто, за 5 останніх років маємо зростання в 4,6 рази. Сьогодні, ринок хмарних сервісів - це один із найбільш динамічних світових ІТ-ринків.

Сьогодення характеризується тенденціями зміни глобальних пріоритетів та проникненням інформаційних технологій у середовище інших галузей, набуттям більш ширшого попиту серед населення світу.

Попри глобальну економічну кризу, через пандемію Covid-19, IT-галузі продовжує бути затребуваною на ринку послуг. Навіть за умов тотальної економії, пандемія спровокувала ситуацію, що спонукає підприємства й державний сектор витрачати гроші на
IT за будь-яких обставин, для багатьох підприємств, це стало засобом виживання. Отже, не зважаючи на те, що прогнозованих прибутків у 2020 р. IT сектору, скоріш за все, отримати не вдасться, можемо казати про те, що ця галузь буде однією 3 найменш постраждалих внаслідок кризи, спричиненої Covid-19. Тимчасове скорочення попиту на послуги IT $\epsilon$ наслідком відкладеного попиту, який із часом треба буде задовольнити, отже можемо прогнозувати нормалізацію і зростання IT-ринку в наступні роки, після кризових потрясінь.

Сьогодні постачальники програмного забезпечення допомагають компаніям будь-якого розміру та будь-якої галузі виживати, зростати та розвиватися. Розглянемо десятку найдохідніших IT-компаній світу, у 2020 р. (рис. 1). Усі вони мають найвищий дохід станом на 18 листопада 2020 р. [6].

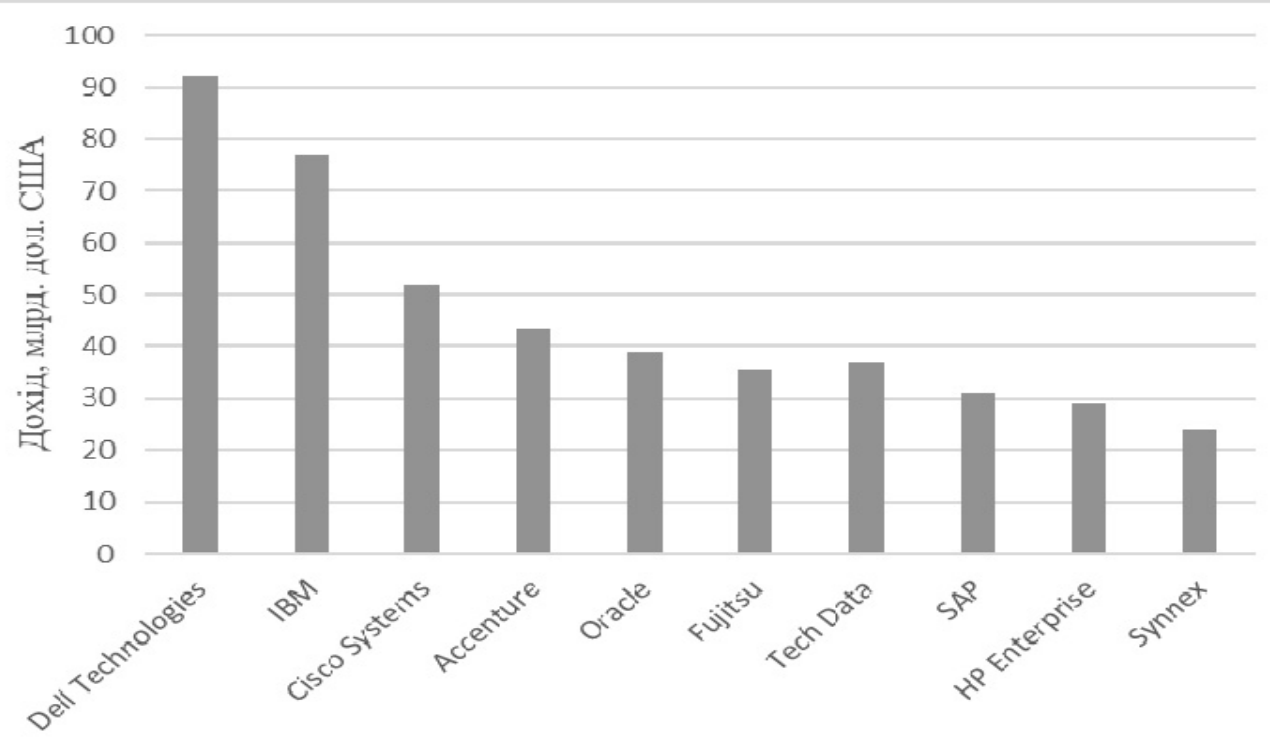

Назва компанії

Рис. 1. Топ 10 найдохідніших IT компаній світу у 2020 р. [складено автором за матеріалом [6]]

У рейтинг увійшли в основному компанії США, країни з розвиненою постіндустріальною економікою. Майже 80 \% ВВП США приходиться на сферу послуг, що зробило їх світовим лідером у цьому сегменті. Матеріальне виробництво складає всього $20 \%$ ВВП, включаючи всі галузі, сільське й лісове господарство, будівництво. Крім того, попри значну частку сільського господарства на світовому ринку, сільське господарство забезпечує менш ніж $1 \%$ ВВП [7].

У науково-дослідницькій роботі автори I.I. Ковальчук та Л.Г. Саркісян виявили, що американська економічна система - одна з найбільш ефективних систем тому, що однією із відмінних рис економічної системи $\epsilon$ орієнтація на науково-технічний прогрес, техноло- гічне обладнання й напрям його впровадження у виробництво. США - світовий лідер з експорту ліцензій на свої винаходи, новітні розробки і відкриття. Цьому сприяє також те, що Сполучені Штати активно працюють над стимулюванням припливу експертів 3 інших країн, запрошуючи їх приєднатися до своїх наукових лабораторій і забезпечуючи більш сприятливі умови для діяльності, ніж вдома [8].

Згідно з прогнозом консалтингової фірми Cartner [9] у найближчі п'ять років голосові інтерфейси, Інтернет речей (IWT), популярність чат-ботів, демократизація штучного інтелекту (AI), поява великої кількості неправдивої інформації та вплив великих технологічних компаній призведе до переосмислення форми 
діяльності великих технологічних компаній. Прогнозується, що до 2021 р.у найбільш прогресивні торгові компанії почнуть впроваджувати сервіси віртуального й голосового пошуку. Це, так само, вимагатиме від компаній більшого розуміння бажань, інтересів і намірів споживачів. На думку аналітика, консалтингової компанії Cartner, за рахунок впровадження інноваційних технологій виручка веб-сайтів електронної комерції може збільшитися на $30 \%$, водночас також збільшиться коефіцієнт залучення нових клієнтів, задоволеності клієнтів і частки ринку. Також можна стверджувати, що до 2021 р. компаній та організації з розроблення мобільних додатків будуть витрачати майже на $50 \%$ більше грошей на розроблення чат-ботів щорічно. Тобто настає епоха постдодатків, для якої характерно використання віртуальних помічників з ознаками штучного інтелекту (II) i проникнення чат-ботів в усі області комунікацій. У тренді набирає популярності використання технологій речей (Інтернет речей), орієнтовно $95 \%$ електронних пристроїв будуть пов'язані 3 обслуговуванням систем моніторингу, інтелектуальних датчиків і лічильників, а також хмарних систем. Крім того, аналітики консалтингової компанії Cartner віщують перехід від різноспрямованої технологічної інфраструктури до непрямої платформи (цифрової екосистеми) впродовж 3-5 років. Метою є створення принципово нових бізнес-моделей для встановлення відносин між людьми й технологіями.

Отже, підсумовуючи результати проведеного дослідження, зауважимо, що не зважаючи на всесвітню кризу, iї наслідки для сфери IT-технологій не $\epsilon$ руйнівними. Сьогодні в ІТ-індустрії спостерігається незначний спад, проте є такі іï сектори, в яких навпаки спостерігається підйом. Це стосується передусім збільшення ринку хмарних технологій, та систем електронної комерції, набуває популярності використання таких технологій, як Інтернет речей, голосових інтерфейсів, чат-ботів. Найвпливовішими гравцями ринку IT-технологій залишаються компанії США. 3 огляду на поточні тенденції в розвитку IT-технологій, можна сказати, що вони є рушійною силою глобальної трансформації та економічного зростання країн світу, а також підвищують конкурентну перевагу будь-якого суб'єкта економічної діяльності.

\section{Список використаних джерел}

1. Ковальчук I.I., Саркісян Л.Г. Визначення трендів розвитку світового ринку ІКТ під впливом цифровізації. Вісник студентського наукового товариства ДонНУ імені Василя Стуса. 2019. Т. 1. № 11. URL: https://jvestniksss.donnu.edu.ua/article/view/6709

2. Gartner Says Global IT Spending to Reach \$3.9 Trillion in 2020. URL: https://www.gartner.com/en/newsroom/pressreleases/2020-01-15-gartner-says-global-it-spending-to-reach3point9-trillion-in-2020

3. Gartner Says Global IT Spending to Decline $8 \%$ in 2020 Due to Impact of COVID-19. URL: https:/www.gartner.com/en/newsroom/press-releases/2020-0513-gartner-says-global-it-spending-to-decline-8-percent-in2020-due-to-impact-of-covid19
4. Gartner Forecasts Worldwide Public Cloud Revenue to Grow 17.5 Percent in 2019. URL: https://www.gartner.com/en/newsroom/press-releases/2019-0402-gartner-forecasts-worldwide-public-cloud-revenue-to-g

5. Усі там будемо: що таке хмарні сервіси й чому вони так стрімко розвиваютья. URL: https://businessviews.com.ua/ru/tech/id/hmari-dlja-biznesu2003/

6. Top Ten Most Profitable IT Companies in the World 2020. FXSSI. URL: https://fxssi.com/most-profitable-itcompanies

7. Distribution of gross domestic product (GDP) across economic sectors in the United States from 2000 to 2017. URL: https://www.statista.com/statistics/270001/distribution-of-grossdomestic-product-gdp-across-economic-sectors-in-the-us/

8. Довгань Л.Є., Козинець А.В. Розвиток ІТ-сфери: проблеми та шляхи вирішення в забезпеченні конкурентоспроможності вітчизняних підприємств. Актуальні проблеми економіки та управління: збірник наукових праць молодих вчених. 2018. Вип. 12. URL: https://ela.kpi.ua/handle/123456789/24607

9. Gartner 2020 Hype Cycle for Emerging Technologies. What's in It for AI Leaders? URL: https://medium.com/swlh/gartner-2020-hype-cycle-foremerging-technologies-whats-in-it-for-ai-leaders-a66eb4768b1

\section{$\underline{\text { References }}$}

1. Kovalchuk I.I., Sarkisian L.H. Identifying trends in the global ICT market under the influence of digitalization. Bulletin of the student scientific society of DonNU after Vasyl Stus. 2019. Vol. 1. № 11. URL: https://jvestniksss.donnu.edu.ua/article/view/6709 (in Ukrainian).

2. Gartner Says Global IT Spending to Reach \$3.9 Trillion in 2020. URL: https://www.gartner.com/en/newsroom/pressreleases/2020-01-15-gartner-says-global-it-spending-to-reach3point9-trillion-in-2020

3. Gartner Says Global IT Spending to Decline $8 \%$ in 2020 Due to Impact of COVID-19. URL: https://www.gartner.com/en/newsroom/press-releases/2020-0513-gartner-says-global-it-spending-to-decline-8-percent-in2020-due-to-impact-of-covid19

4. Gartner Forecasts Worldwide Public Cloud Revenue to Grow 17.5 Percent in 2019. URL: https://www.gartner.com/en/newsroom/press-releases/2019-0402-gartner-forecasts-worldwide-public-cloud-revenue-to-g

5. We will all be there: what are cloud services and why they are developing so rapidly URL: https://businessviews.com.ua/ru/tech/id/hmari-dlja-biznesu2003/ (in Ukrainian).

6. Top Ten Most Profitable IT Companies in the World 2020. FXSSI. URL: https://fxssi.com/most-profitable-itcompanies

7. Distribution of gross domestic product (GDP) across economic sectors in the United States from 2000 to 2017. URL: https://www.statista.com/statistics/270001/distribution-of-grossdomestic-product-gdp-across-economic-sectors-in-the-us/

8. Dovhan L.Y., Kozynets A.V. Development of the IT sphere: problems and solutions in ensuring the competitiveness of domestic enterprises. Current problems of economics and management: a collection of scientific works of young scientists. 2018. Issue $12 . \quad$ URL: https:/ela.kpi.ua/handle/123456789/24607 (in Ukrainian).

9. Gartner 2020 Hype Cycle for Emerging Technologies. What's in It for AI Leaders? URL: https://medium.com/swlh/gartner-2020-hype-cycle-foremerging-technologies-whats-in-it-for-ai-leaders-a66eb4768b1 